\title{
Triterpenoid Glycosides from Olax imbricata
}

\author{
Vo Thi Nga ${ }^{1}$, Huynh Thi Minh Suong ${ }^{2}$, Nguyen Thi My Huong ${ }^{3}$, Duong Thuc Huy ${ }^{4}$, Nguyen Kim Phi Phung ${ }^{3, *}$
}

${ }^{1}$ Department of Chemical Technology, Ho Chi Minh City University of Technology and Education, 1 Vo Van Ngan Str., Thu Duc Dist., Ho Chi Minh City, Vietnam

${ }^{2}$ Department of General Science, University of Natural Resources and Environment Ho Chi Minh City, 236B Le Van Sy Str., Tan Binh Dist., Ho Chi Minh City, Vietnam

${ }^{3}$ Department of Organic Chemistry, University of Science, National University - Ho Chi Minh City, 227 Nguyen Van Cu Str., Dist. 5, Ho Chi Minh City, Vietnam

${ }^{4}$ Department of Chemistry, Ho Chi Minh City University of Education, 280 An Duong Vuong Str., Dist. 5, Ho Chi Minh City, Vietnam

\section{Correspondence}

Nguyen Kim Phi Phung, Department of Organic Chemistry, University of Science, National University - Ho Chi Minh City, 227 Nguyen Van Cu Str., Dist. 5, Ho Chi Minh City, Vietnam

Email: kimphiphung@yahoo.fr

History

- Received: 2019-03-07

- Accepted: 2019-08-09

- Published: 2019-08-30

DOI :

DOI :
https://doi.org/10.32508/stdj.v22i3.1660

\section{Check for updates}

\section{Copyright}

(C) VNU-HCM Press. This is an openaccess article distributed under the terms of the Creative Commons Attribution 4.0 International license.

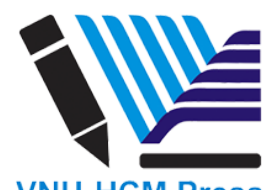

\begin{abstract}
Introduction: Olax imbricata, owning antibacterial, antioxidant, and anti-inflammatory activities, has been investigated as one of traditional diabetic plants in Vietnam. In our previous publications on Olax imbricata, the structure analysis of the isolated compounds were reported, including two phenolic compounds, three phenolic glycosidic compounds, a sesquiterpenoid tropolone and 1,2,3,4-tetrahydronaphthalene derivatives. This article described the isolation and structure elucidation of three triterpenoid glycosides isolated from the methanol extract of Olax imbricata growing in Phu Yen province. Additionally, the evaluation of inhibitory activity for $\alpha$-glucosidase was performed on a pure compound. Method: The methanol extract of this plant applied the chromatographic techniques, including thin-layer chromatography and silica gel column chromatography, led to the isolation of three pure compounds. The structures of three isolated compounds were elucidated by the spectroscopic data, including 1D and 2D NMR spectra in a combination of HRESIMS, and the sugar moieties were elucidated by acid hydrolysis. The $\alpha$-glucosidase inhibitory assay was applied to a pure compound by the colorimetric method. Results: Three triterpenoid glycosides, namely 3-O- $\alpha$-L-rhamnopyranosyl-( $1 \rightarrow 4)-\beta$-D-glucopyranosyl-( $1 \rightarrow 3$ )-6'- O-ethyl- $\beta$-Dglucuronyl oleanolic acid (1), oleanolic acid 28-O- $\beta$-D-glucopyranoside (2) and spergulacin (3) were isolated and elucidated. The compound $\mathbf{2}$ showed its strong potential $\alpha$-glucosidase inhibitory activity with the $\mathrm{IC}_{50}$ value of $56.15 \pm 1.31 \mu \mathrm{M}$. Conclusion: Among them, compound $\mathbf{1}$ is a new one, the compounds $\mathbf{2}$ and $\mathbf{3}$ were isolated for the first time from the genus Olax. The compound $\mathbf{2}$ exhibited the potential $\alpha$-glucosidase inhibition activity, contributing to demonstrating the diabetes treatment ability of Olax imbricata in the folklore.

Key words: Olax imbricata, triterpenoid, glycoside, $\alpha$-glucosidase inhibition
\end{abstract}

\section{INTRODUCTION}

Olax, the largest genus of Olacaceae with about 40 species, growing in Africa, SouthEast Asia and Australia, displayed interesting bioactivities. In 2012, Nwaigwe CU researched on the methanolic extract of $O$. viridis roots and investigated its potential protecting ability against liver damage caused by acetaminophen ${ }^{1}$. The study from Adeoluwa OA's group indicated that the ethanolic extract from O. supscorpioidea leaves with its anticonvulsant activity could reduce the pain ${ }^{2}$. This extract also possessed potential analgesic activity ${ }^{3}$. O. mannii has been used as folk remedies for the treatment of fever, yellow fever, and snake bite. The acetone extract of this species was also researched by Sule MI in $2011^{4}$ and investigated rhoiptelenol and glutinol, belonging the triterpenoid group. The Olax genus was demonstrated owning such potential bioactivities, but the chemical investigation on this genus has been rarely researched. From three Olax species, including O. glabriflora, O. psittacorum , and $O$. andronensis, olaxoside, a saponin owning laxative and anti-inflammatory activities, was isolated in 1981 by Forgacs $\mathrm{P}^{5}$. An amino acid,
$S$-ethenylcysteine, was separated from $O$. phyllanthi roots by Peter PT in $1993^{6}$. (2 E)-3-Methyl-5-phenyl2-pentenoic acid was yielded from O. manni leaves in $2005^{7}$. Okoye FBC separated olamannoside A$\mathrm{C}^{8}$ and olamannoside $\mathrm{D}-\mathrm{E}^{9}$ from $\mathrm{O}$. mannii leaves in 2015 and 2016, respectively.

The phytochemical analysis of $O$. imbricata has been rarely investigated. The research of Kannika $\mathrm{P}$ in Thailand revealed the presence of flavonoids, polyphenolic compounds, glycosides, tannins, saponins, alkaloids. The bioactivity assay indicated that some of these compounds owned the antioxidant and antibacterial activities ${ }^{10}$. In our previous publications on Olax imbricata, the structure analysis of the isolated compounds were reported, including two phenolic compounds, as 1-O-(4hydroxy-2,6-dimethoxyphenyl)-6-O-(4-hydroxy3,5 -dimethoxybenzoyl)- $\beta$-D-glucopyranose and 1 O-(4-hydroxy-2-methoxyphenyl)-6-O-(4-hydroxy3,5-dimethoxybenzoyl)- $\beta$-D-glucopyranose ${ }^{11}$, three phenolic glycosidic compounds, as 1(3,4-dihydroxyphenyl)-8-(4-hydroxy-3-O- $\beta$-Dglucopyranosylphenyl)oct-5-ol-4-one, $\quad(4 \quad$ E)-1- 
(3,4-dihydroxyphenyl)-7-(3-hydroxy-4-O- $\beta$-Dglucopyranosylphenyl)hept-4-ene-6-ol-3-one and leonuriside $\mathrm{A}^{12}$, a sesquiterpenoid tropolone, namely olaximbriside A and 1,2,3,4-tetrahydronaphthalene derivatives, as olaximbrisides $\mathrm{B}-\mathrm{D}^{13}$.

Continuing our research about the chemical composition of Olax imbricata, one of the traditional diabetic plants in Vietnam, this study focused on the isolation of triterpenoid glycosides and the $\alpha$-glucosidase inhibitory assay, with the expectation of isolating bioactivity compounds. The isolation was carried out on the methanol extract, which is a rich source of triterpenoid glycosides. In this article, we report the isolation of three triterpenoid glycosides and the structure elucidation using 1D, 2D NMR, and HRESIMS analysis, as well as acid hydrolysis technique for identifying the nature of the sugar moieties. The $\alpha$-glucosidase inhibition activity assay was performed on a pure compound, and the potential result was obtained.

\section{METHODS}

\section{General experimental procedures}

The 1D and 2D NMR spectra were acquired using a Bruker Avance spectrometer, at $500 \mathrm{MHz}$ for ${ }^{1} \mathrm{H}$ NMR and $125 \mathrm{MHz}$ for ${ }^{13} \mathrm{C}-\mathrm{NMR}$. Chemical shifts are referenced to the residual solvent signal: DMSO$\mathrm{d}_{6} \mathrm{~d}_{H} 2.50 \mathrm{ppm}$ and $\mathrm{d}_{C} 39.5 \mathrm{ppm}$. The HRESIMS spectra were measured on Bruker microTOF Q-II spectrometer. The absorbance of the samples for $\alpha$ glucosidase inhibitory assay was measured on BioTek microplate spectrophotometer (USA). Column chromatography was carried out on silica gel (0.040-0.063 $\mathrm{mm}$ ) from HiMedia (Mumbai, India). TLC analyses were performed on pre-coated silica gel 60 F254 or silica gel 60 RP-18 F254S purchased from Merck (Darmstadt, Germany). $\alpha$-Glucosidase (G0660), p-nitrophenyl- $\alpha$-D-glucopyranoside (N1377), phosphate buffer (P4417), acarbose (A8980) were purchased from Sigma-Aldrich (St. Louis, MO, USA); dimethyl sulfoxide from Fisher Scientific (Pittsburgh, PA, USA). Other chemicals were obtained from Chemsol ViNa (Vietnam).

\section{Plant material}

The roots of Olax imbricata were collected in Dong Hoa, Phu Yen province, Vietnam. A voucher specimen (No US-C027) was deposited in the herbarium of the Department of Organic Chemistry, University of Science, National University - Ho Chi Minh City.

\section{Extraction and isolation}

Dried and finely powdered roots $(6.3 \mathrm{~kg})$ were exhaustively macerated with ethanol at ambient temperature to afford a crude residue $(1.2 \mathrm{~kg})$. This residue was extracted to form different extracts by dissolving the residue consecutively in $n$-hexane, then ethyl acetate and finally in methanol. The $n$-hexane-solute was evaporated to dryness under low pressure to obtain the $n$-hexane extract ( $500 \mathrm{~g}$ ). The similar process was separately applied for the ethyl acetate and methanol solutes to afford the ethyl acetate extract $(70 \mathrm{~g})$ and the methanol extract ( $430 \mathrm{~g}$ ), respectively.

The methanol extract (430 g) was applied to normal phase column chromatography using silica gel and the solvent system as gradient elution of ethyl acetatemethanol (95:5-1:1) to yield ten fractions (A1-A10). Fraction A1 (35.0 g) was chromatographed on silica gel column with the elution of chloroform:methanol (98:2) to give 10 sub-fractions (A1.1- A1.10). The column chromatographic method was used on the subfraction A1.7 (3.0 g) eluted with chloroform:methanol (9:1) led to the isolation of compound 3 (5 mg). The same method was carried out on the sub-fraction A1.8 $(12.0 \mathrm{~g})$, eluted with ethyl acetate: methanol: water (8:1:1) to obtain compound $\mathbf{1}(5 \mathrm{mg})$ and $\mathbf{2}(6 \mathrm{mg})$.

\section{Acid Hydrolysis of 1 and 3}

Compound $\mathbf{1}$ and compound $\mathbf{3}$ were separately hydrolyzed in an acid solution to obtain the sugar residues. Each compound ( $2 \mathrm{mg}$ ) was treated with $\mathrm{HCl} 0.2 \mathrm{M}$ (dioxane $/ \mathrm{H}_{2} \mathrm{O}, 1 / 1, v / v, 200 \mu \mathrm{L}$ ) at $95^{\circ} \mathrm{C}$ for $3 \mathrm{hrs}$. After cooling, the reaction mixture was extracted with chloroform $(3 \times 2 \mathrm{~mL})$ to separate and the sugar and the aglycone component. The aqueous solution was evaporated to dryness and then dissolved in $\mathrm{D}_{2} \mathrm{O}$ for further ${ }^{1} \mathrm{H}$ NMR measurement. The hydrolyzed monosaccharides were identified by the ${ }^{1} \mathrm{H}$ NMR analysis ${ }^{14}$.

\section{$\alpha$-Glucosidase inhibition assay}

The $\alpha$-glucosidase inhibitory assay was performed on compound 2 , as described by Hakamata ${ }^{15}$, with some modifications. The assay was performed in a 96 well plate with the total reaction volume of $200 \mathrm{~mL}$ per well. The reaction components included $40 \mu \mathrm{L}$ $0.1 \mathrm{M}$ phosphate buffer solution ( $\mathrm{pH}$ 6.8), $25 \mu \mathrm{L} \alpha$ glucosidase $(0.2 \mathrm{unit} / \mathrm{mL}), 10 \mu \mathrm{L}$ test sample, $25 \mu \mathrm{L}$ p-nitrophenyl $\alpha$-D-glucopyranoside (2.5 mM).

The test samples, dissolved in DMSO at some concentrations, were mixed with enzyme solution. The microplate wells with all the reagents were incubated for $30 \mathrm{~min}$ at $37^{\circ} \mathrm{C}$. The reaction was terminated 


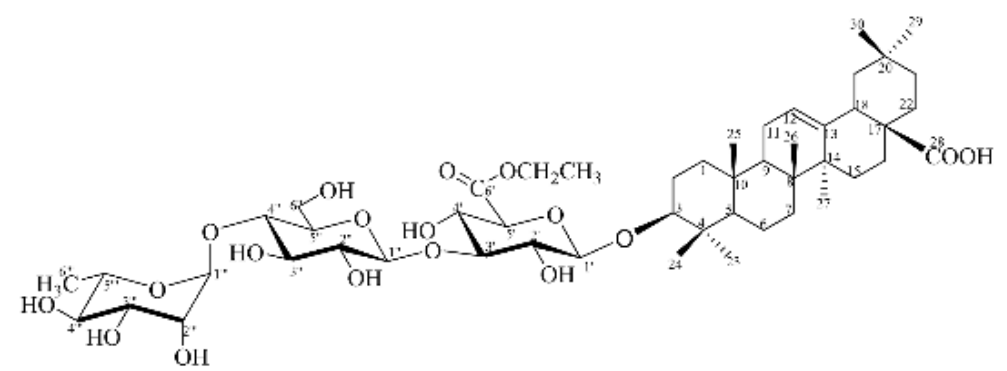

3- $O$ - $\alpha$-L-Rhamnopyranosyl-( $(1 \rightarrow 4)-\beta$-D-glucopyranosyl-( $(1 \rightarrow 3)-6$ '- $O$-ethyl$\beta$-D-glucuronyl oleanolic acid (1)

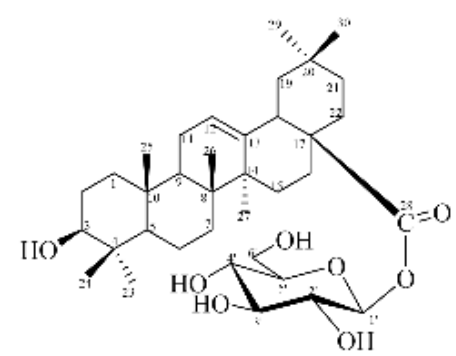

Oleanolic acid 28-O- $\beta$-D-glucopyranoside (2)

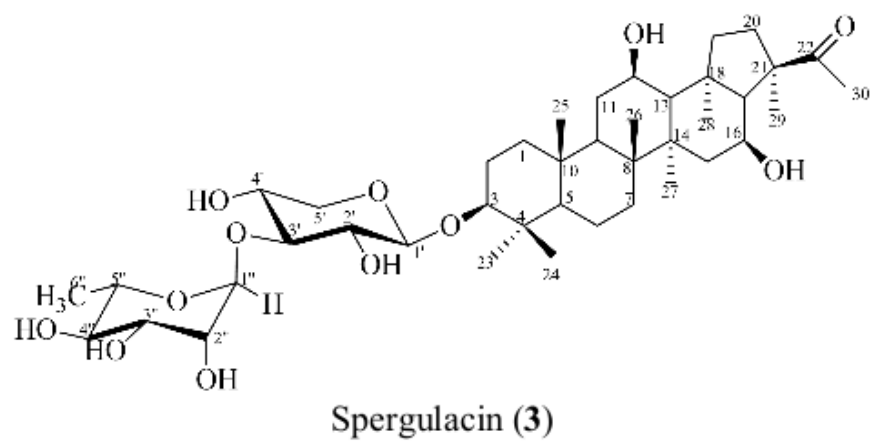

Figure 1: The structures of the isolated compounds 1-3.

by adding $100 \mu \mathrm{L}$ of $0.2 \mathrm{M}$ sodium carbonate solution. The system without a test sample replaced by the buffer solution was used as a negative control, and the positive control was acarbose. Each experiment was carried out in triplicate. The absorbance of the samples was measured with a BIOTEK microplate reader at $410 \mathrm{~nm}$.

The $\alpha$-glucosidase inhibitory percentage of the test sample was calculated through the equation:

$$
\mathrm{I}(\%)=\frac{\mathrm{A}_{\text {(negative control) }}-\mathrm{A}_{(\text {test sample) }}}{\mathrm{A}_{\text {(negative control) }}} \times 100 \%
$$

Where: I (\%) as $\alpha$-glucosidase inhibitory percentage;
A as absorbance.

The $\mathrm{IC}_{50}$ (the half-maximal inhibitory concentration) was determined by the calibration curve equation between percentages of inhibition and sample concentration using Tablecurve software.

\section{Statistical analysis}

Each experiment for the $\alpha$-glucosidase inhibitory assay was carried out in triplicate. Statistical analysis method was performed with Tablecurve software. 
Table 1: ${ }^{13}$ C NMR spectroscopic data* of aglycones of compounds 1-3

\begin{tabular}{|c|c|c|c|}
\hline Position & Compound 1 & Compound 2 & Compound 3 \\
\hline 1 & 36.3 & 38.2 & 38.2 \\
\hline 2 & 25.5 & 27.0 & 25.8 \\
\hline 3 & 88.4 & 77.7 & 87.9 \\
\hline 4 & 40.0 & 40.0 & 39.0 \\
\hline 5 & 54.9 & 54.9 & 54.7 \\
\hline 6 & 17.8 & 18.0 & 17.8 \\
\hline 7 & 32.1 & 31.6 & 32.8 \\
\hline 8 & 39.0 & 36.6 & 44.7 \\
\hline 9 & 47.0 & 47.2 & 48.0 \\
\hline 10 & 38.6 & 38.4 & 36.2 \\
\hline 11 & 22.9 & 23.0 & 31.5 \\
\hline 12 & 121.5 & 121.7 & 67.3 \\
\hline 13 & 143.8 & 143.5 & 54.5 \\
\hline 14 & 41.3 & 41.3 & 40.9 \\
\hline 15 & 27.2 & 27.2 & 44.4 \\
\hline 16 & 22.6 & 22.5 & 64.1 \\
\hline 17 & 45.4 & 45.6 & 62.9 \\
\hline 18 & 40.8 & 40.8 & 46.0 \\
\hline 19 & 45.7 & 46.0 & 44.6 \\
\hline 20 & 30.4 & 30.3 & 36.2 \\
\hline 21 & 33.3 & 33.3 & 52.2 \\
\hline 22 & 32.4 & 32.3 & 213.8 \\
\hline 23 & 27.4 & 28.2 & 27.4 \\
\hline 24 & 16.3 & 16.1 & 16.1 \\
\hline 25 & 15.0 & 15.2 & 15.6 \\
\hline 26 & 16.8 & 16.7 & 16.6 \\
\hline 27 & 25.5 & 25.6 & 18.5 \\
\hline 28 & 178.5 & 175.3 & 17.2 \\
\hline 29 & 32.8 & 32.8 & 20.1 \\
\hline 30 & 23.4 & 23.4 & 25.8 \\
\hline
\end{tabular}




\section{RESULTS AND DISCUSSION}

\section{Results}

\section{Structural elucidation}

The phytochemistry investigation on the methanol extract of the roots of Olax imbricata led to the isolation of three triterpenoid glycosides 1-3 whose structures were performed in Figure 1. The spectroscopic properties of three isolated compounds were displayed as following.

Compound 1: White amorphous powder. HRESIMS $m / z 991.5209[\mathrm{M}+\mathrm{Na}]^{+} .{ }^{1} \mathrm{H}$ NMR $\left(\right.$ DMSO-d $\left._{6}\right): \delta$ $0.99,0.75,0.86,0.72,1.09,0.87,0.87$ (each $3 \mathrm{H}, s, \mathrm{H}_{3}$ of C-23, C-24, C-25, C-26, C-27, C-29, C-30), 3.09 (1H, $d d, J=11.0,5.0 \mathrm{~Hz}, \mathrm{H}-3), 2,74(1 \mathrm{H}, d d, J=13.5,4.0$ $\mathrm{Hz}, \mathrm{H}-18$ ), 1.65 (m, H-1), 0.71 (m, H-6), 1.57, 138 (m, H-7), 1.49 (m, H-9), 1.80 (m, H-11), 5.15 (m, H-12), 1.64 (m, H-15), 1.49 (m, H-16), 1.64 (m, H-19), 1.18, 1.31 (m, H-21), 1.41, 1.59 (m, H-22). ${ }^{13} \mathrm{C}-\mathrm{NMR}$ spectroscopic data (DMSO- $\mathrm{d}_{6}$ ): Table 1. Sugar moiety: Table 2.

Compound 2: White amorphous powder. ${ }^{1} \mathrm{H}$ NMR $\left(\right.$ DMSO-d $_{6}$ ): $\delta 0.89,0.69,0.67,0.87,1.08,0.88,0.85$ (each $3 \mathrm{H}, s, \mathrm{H}_{3}$ of C-23, C-24, C-25, C-26, C-27, C29, C-30), $3.00(1 \mathrm{H}, d d, J=10.5,5.5 \mathrm{~Hz}, \mathrm{H}-3), 2.74$ $(1 \mathrm{H}, d d, J=14.0,4.5 \mathrm{~Hz}, \mathrm{H}-18), 1.15(1 \mathrm{H}, d, J=13.5$ $\mathrm{Hz}, \mathrm{H}-21), 1.38$ (m, H-21), $1.15(1 \mathrm{H}, d, J=13.5 \mathrm{~Hz}$, H-22), 1.38 (m, H-22), 1.54 (m, H-1), 1.75 (m, H-2), 0.66 (m, H-5), 1.27, 1.47 (m, H-6), 1.54 (m, H-7), 1.50 (m, H-9), 1.80 (m, H-11), 5.15 (m, H-12), 1.47, 1.73 (m, H-15), 1.95 (m, H-16), 1.63 (m, H-19). ${ }^{13} \mathrm{C}-\mathrm{NMR}$ spectroscopic data (DMSO- $\mathrm{d}_{6}$ ): Table 1. Sugar moiety: Table 2.

Compound 3: White amorphous powder. HRESIMS $m / z 775.4592[\mathrm{M}+\mathrm{Na}]^{+} .{ }^{1} \mathrm{H}$ NMR $\left(\right.$ DMSO-d $\left._{6}\right): \delta$ 0.95, 0.74, 0.77, 0.95, 0.90, 0.91, 1.24, 2.09 (each 3H, $s, \mathrm{H}_{3}$ of C-23, C-24, C-25, C-26, C-27, C-28, C-29, C30), $3.00(1 \mathrm{H}, d d, J=11.5,4.5 \mathrm{~Hz}, \mathrm{H}-3), 0.67(1 \mathrm{H}, d, J$ $=11.0 \mathrm{~Hz}, \mathrm{H}-5), 3.96(1 \mathrm{H}, d, J=7.5 \mathrm{~Hz}, 12-\mathrm{OH}), 1.30$ $(1 \mathrm{H}, d, J=10.5 \mathrm{~Hz}, \mathrm{H}-13), 4.10(1 \mathrm{H}, d, J=5.6 \mathrm{~Hz}$, 16-OH), $1.61(1 \mathrm{H}, d, J=11.4 \mathrm{~Hz}, \mathrm{H}-17), 2.00(1 \mathrm{H}$, $d d, J=12.5,7.0 \mathrm{~Hz}, \mathrm{H}-19), 1.33$ (m, H-19), 1.56, 0.91 (m, H-1), 1.68, 1.55 (m, H-2), 1.35 (m, H-6), 1.69, 1.20 (m, H-7), 1.18 (m, H-9), 1.37, 1.16 (m, H-11), 3.69 (m, H-12), 1.40, 1.15 (m, H-15), 3.58 (m, H-16), 1.74, 1.49 (m, H-20). ${ }^{13} \mathrm{C}-\mathrm{NMR}$ spectroscopic data (DMSO- $\mathrm{d}_{6}$ ): Table 1. Sugar moiety: Table 2. 


\begin{tabular}{|c|c|c|c|c|c|c|}
\hline \multirow[t]{2}{*}{ POS. } & \multicolumn{2}{|c|}{ Compound 1} & \multicolumn{2}{|c|}{ Compound 2} & \multicolumn{2}{|c|}{ Compound 3} \\
\hline & $\begin{array}{c}\delta \mathbf{H}(\mathrm{J} \text { in } \\
\mathbf{H z})\end{array}$ & $\delta \mathrm{C}$ & $\begin{array}{c}\delta \mathrm{H}(\mathrm{J} \text { in } \\
\mathbf{H z})\end{array}$ & $\delta \mathrm{C}$ & $\delta \mathbf{H}(\mathrm{J}$ in $\mathbf{H z})$ & $\delta \mathrm{C}$ \\
\hline & \multicolumn{2}{|c|}{$O$-Ethyl- $\beta$-D-glucuronate } & \multicolumn{2}{|c|}{$\beta$-D-Glucopyranose } & \multicolumn{2}{|c|}{$\beta$-D-Xylopyranose } \\
\hline $1^{\prime}$ & $4.44(\mathrm{~d}, 7.5)$ & 104.7 & $\begin{array}{c}5.24(\mathrm{~d} \\
8.0)\end{array}$ & 94.1 & $4.15(\mathrm{~d}, 7.5)$ & 105.8 \\
\hline $2^{\prime}$ & $3.27(\mathrm{~m})$ & 74.7 & $3.12(\mathrm{~m})$ & 72.4 & $3.09(\mathrm{~m})$ & 74.0 \\
\hline $2^{\prime}-\mathrm{OH}$ & $5.31(\mathrm{~d}, 4.5)$ & - & - & - & $5.20(\mathrm{~d}, 5.5)$ & - \\
\hline $3^{\prime}$ & $3.43(\mathrm{~m})$ & 86.7 & $3.25(\mathrm{~m})$ & 76.9 & $3.30(\mathrm{~m})$ & 80.8 \\
\hline $4^{\prime}$ & $3.45(\mathrm{~m})$ & 70.5 & $3.10(\mathrm{~m})$ & 69.6 & $3.87(\mathrm{~m})$ & 68.2 \\
\hline $4^{\prime}-\mathrm{OH}$ & $4.89(\mathrm{~m})$ & - & & & & \\
\hline $5^{\prime}$ & $3.81(\mathrm{~m})$ & 74.7 & $3.15(\mathrm{~m})$ & 76.7 & $\begin{array}{c}3.66(\mathrm{~d}, 9.0), 3.09(\mathrm{~d}, \\
11.5)\end{array}$ & 65.4 \\
\hline $6^{\prime}$ & - & 168.6 & $\begin{array}{c}3.62(1 \mathrm{H}, \\
d d, 5.0, \\
11.5) 3.45 \\
(1 \mathrm{H}, d d, \\
5.5,11.5)\end{array}$ & 60.7 & - & - \\
\hline $6^{\prime}-$ & $4.13(\mathrm{~m})$ & 60.6 & & & & \\
\hline \multicolumn{7}{|l|}{$\mathrm{OCH}_{2}$} \\
\hline$-\mathrm{CH}_{3}$ & $1.19(\mathrm{t}, 7.0)$ & 13.9 & & & & \\
\hline \multicolumn{3}{|c|}{$\beta$-D-Glucopyranose } & & & \multicolumn{2}{|c|}{$\alpha$-L-Rhamnopyranose } \\
\hline $1^{\prime \prime}$ & $\begin{array}{c}4.35(1 \mathrm{H}, d, \\
7.5)\end{array}$ & 103.6 & & & $5.01(\mathrm{~s})$ & 100.5 \\
\hline $2^{\prime \prime}$ & $3.24(\mathrm{~m})$ & 77.0 & & & $3.48(\mathrm{~m})$ & 70.6 \\
\hline $2^{\prime \prime}-\mathrm{OH}$ & $4.89(\mathrm{~m})$ & - & & & $4.54(\mathrm{~d}, 4.0)$ & - \\
\hline $3^{\prime \prime}$ & $3.21(\mathrm{~m})$ & 74.6 & & & $3.46(\mathrm{~m})$ & 70.6 \\
\hline $3^{\prime \prime}-\mathrm{OH}$ & $5.10(\mathrm{~m})$ & - & & & $4.43(\mathrm{~d}, 5.5)$ & - \\
\hline $4^{\prime \prime}$ & $3.41(\mathrm{~m})$ & 80.5 & & & $3.19(\mathrm{~m})$ & 72.0 \\
\hline $4^{\prime \prime}-\mathrm{OH}$ & - & - & & & $4.60(\mathrm{~d}, 5.0)$ & - \\
\hline $5^{\prime \prime}$ & $3.11(\mathrm{~m})$ & 68.1 & & & $3.51(\mathrm{~m})$ & 68.0 \\
\hline \multirow[t]{2}{*}{$6^{\prime \prime}$} & $\begin{array}{c}3.67(\mathrm{~m}), \\
3.39(1 \mathrm{H}, d \\
9.0)\end{array}$ & 61.0 & & & $1.08(\mathrm{~d}, 6.0)$ & 18.5 \\
\hline & $\alpha$-L-Rham & ranose & & & & \\
\hline $1^{\prime \prime \prime}$ & $5.02(b r s)$ & 100.4 & & & & \\
\hline $2^{\prime \prime \prime}$ & $3.70(\mathrm{~m})$ & 70.6 & & & & \\
\hline $2^{\prime \prime \prime}-\mathrm{OH}$ & $4.58(\mathrm{~m})$ & - & & & & \\
\hline $3^{\prime \prime \prime}$ & $3.51(\mathrm{~m})$ & 70.1 & & & & \\
\hline $3^{\prime \prime \prime}-\mathrm{OH}$ & $4.60(\mathrm{~m})$ & - & & & & \\
\hline $4^{\prime \prime \prime}$ & $3.19(\mathrm{~m})$ & 72.0 & & & & \\
\hline $4^{\prime \prime \prime}-\mathrm{OH}$ & $4.56(\mathrm{~m})$ & - & & & & \\
\hline $5^{\prime \prime \prime}$ & $3.89(\mathrm{~m})$ & 68.5 & & & & \\
\hline $6^{\prime \prime \prime}$ & $1.08(\mathrm{~d}, 6.5)$ & 17.7 & & & & \\
\hline
\end{tabular}

${ }^{*}$ Recorded in DMSO- $\mathrm{d}_{6}$ at $500 \mathrm{MHz}$ for ${ }^{1} \mathrm{H}$ NMR and at $125 \mathrm{MHz}$ for ${ }^{13} \mathrm{C}$ NMR. Chemical shifts $(\delta)$ are expressed in ppm, and $J$ values are presented in $\mathrm{Hz}$. 


\section{In vitro $\alpha$-glucosidase inhibitory assay}

Compound 2 was evaluated for its potential $\alpha$ glucosidase inhibitory activity assay using the Hakamata's method with some modification ${ }^{15}$. Acarbose was used as a positive control. Compounds $\mathbf{1}$ and $\mathbf{3}$ were not tested this assay because their small amount yielded and needed to be hydrolyzed for the identification of oligosaccharides. The result of the $\alpha$ glucosidase inhibitory assay on compound 2 was presented in Table 3.

\begin{tabular}{|c|c|}
\hline Compounds & $\mathbf{I C}_{50}(\mu \mathbf{M})^{a}$ \\
\hline 2 & $56.15 \pm 1.31$ \\
\hline Acarbose $^{b}$ & $290.59 \pm 5.25$ \\
\hline
\end{tabular}

\section{DISCUSSION}

Compound $\mathbf{1}$ was yielded as a white amorphous powder. It was assigned the molecular formula, $\mathrm{C}_{50} \mathrm{H}_{80} \mathrm{O}_{18}$, as elucidated by ${ }^{13} \mathrm{C}$ NMR and positive HR ESIMS. The HRESIMS of $\mathbf{1}$ displayed a $[\mathrm{M}+\mathrm{Na}]^{+}$ ion at $m / z 991.5209$ (calcd. 991.5242 for $\mathrm{C}_{50} \mathrm{H}_{80} \mathrm{O}_{1}$ $\mathrm{Na})$. The ${ }^{1} \mathrm{H}$ NMR spectrum of $\mathbf{1}$ showed signals for seven tertiary methyl groups $\left(\delta_{H} 0.72,0.75,0.86\right.$, $0.87,0.87,0.99,1.09)$, a typical signal of the axial proton at C-3 at $\delta_{H} 3.09(1 \mathrm{H}, d d, 11.0,5.0 \mathrm{~Hz})$, and a characteristic olefinic proton at $\delta_{H} 5.15(1 \mathrm{H}, \mathrm{m})$ proving for a triterpenoid skeleton. The ${ }^{13} \mathrm{C} \mathrm{NMR}$ spectrum displayed for 30 signals of the aglycone portion, correlating to the corresponding proton chemical shifts from the HSQC experiment. The characteristic signals for the triterpenoid portion were also found in ${ }^{13} \mathrm{C} \mathrm{NMR}$, including two olefinic carbons at $\delta_{C} 121.5(\mathrm{C}-12)$ and $\delta_{C} 143.8$ (C-13) together with a carboxyl group at $\delta_{C} 178.5$ (C-28) and an oxygenated carbon at $\delta_{C} 88.4$ (C-3). Based on the chemical shift and the $J$ value of the proton assigned to C-3 centered at $\delta_{H} 3.09(1 \mathrm{H}, d d, 11.0,5.0$ $\mathrm{Hz}$ ), the $3 \alpha-\mathrm{OH}$ substitution was indicated. All these evidences led to the identification of the aglycone as $3 \alpha$-hydroxyolean-12-ene-28-oic acid or oleanolic acid ${ }^{16}$. In the ${ }^{1} \mathrm{H}$ NMR spectrum, the sugar moiety of 1 exhibited three anomeric proton signals at $\delta_{H}$ $4.44\left(1 \mathrm{H}, d, 7.5 \mathrm{~Hz}, \mathrm{H}-1^{\prime}\right), 4.35\left(1 \mathrm{H}, d, 7.5 \mathrm{~Hz}, \mathrm{H}-1^{\prime \prime}\right)$, $5.02\left(1 \mathrm{H}, b r s, \mathrm{H}-1^{\prime \prime \prime}\right)$ and one methyl doublet at 1.08 $\left(1 \mathrm{H}, d, 6.5 \mathrm{~Hz}, \mathrm{H}-6^{\prime \prime \prime}\right)$ suggesting the occurrence of one deoxyhexose unit. The structures of the oligosaccharide units were deduced by COSY, HSQC, HMBC experiments, which indicated the presence of an ethyl- $\beta$-D-glucuronate unit, a $\beta$-D-glucopyranose unit, and an $\alpha$-L-rhamnopyranose unit. Upon the anomeric proton analysis of the sugar portions obtained by acid hydrolysis, the nature of the sugar moieties was further confirmed. Compound $\mathbf{1}$ was hydrolyzed in a solution of $0.2 \mathrm{M} \mathrm{HCl}$ to afford some monosaccharide units. The anomeric signals of three monosaccharides at $\left[\delta_{H} 5.51(\mathrm{~s}, 80 \%)\right.$ and $\delta_{H} 5.59$ $(\mathrm{d}, 4.0 \mathrm{~Hz}, 20 \%)$ ], [ $\delta_{H} 5.26(\mathrm{~d}, 3.5 \mathrm{~Hz}, 32 \%)$ and $\left.\delta_{H} 4.68(\mathrm{~d}, 7.5 \mathrm{~Hz}, 68 \%)\right]$, and [ $\delta_{H} 5.15$ (s, 51\%), $\delta_{H} 4.90(\mathrm{~s}, 49 \%), \delta_{H} 1.32(\mathrm{~d}, 6.5 \mathrm{~Hz}, 46 \%)$ and $\delta_{H}$ 1.30 (d, $6.5 \mathrm{~Hz}, 54 \%$ ) (for methyl groups)], were consistent with those of the ethylglucuronate unit, glucose unit and rhamnose unit, respectively ${ }^{14}$. The ${ }^{13} \mathrm{C}$-NMR spectrum also showed the presence of an ethoxyl group $\left(\delta_{H} 4.13, \delta_{C} 60.6\right.$ and $\delta_{H} 1.19, \delta_{C}$ 13.9) which attached to the carboxyl carbon C- $6^{\prime}\left(\delta_{C}\right.$ 168.6) of the glucuronic acid unit demonstrated by the HMBC experiment. HMBC correlations of the anomeric proton $\mathrm{H}_{-1}{ }^{\prime}$ at $\delta_{H} 4.44(1 \mathrm{H}, d, 7.5 \mathrm{~Hz})$ to C-3 $\left(\delta_{C} 88.4\right)$ of the aglycone, of $\mathrm{H}-5^{\prime}\left(\delta_{H} 3.81\right)$ to the carboxyl carbon C- $6^{\prime}\left(\delta_{C} 168.6\right)$, and of the protons of the ethoxyl group $\left(\delta_{H} 4.13\right)$ to C-6' defined the presence of an ethyl $\beta$-D-glucuronate unit attached to the aglycone at C-3. Furthermore, the HMBC spectrum exhibited the correlation peaks between the signal of $\mathrm{H}-1^{\prime \prime}\left(\delta_{H} 4.35\right)$ and C-3' $\left.{ }^{\prime} \delta_{C} 86.7\right)$, of $\mathrm{H}-1^{\prime \prime \prime}$ $\left(\delta_{H}\right.$ 5.02) and C-4 $4^{\prime \prime}\left(\delta_{C}\right.$ 80.5) suggesting that the $\beta$-D-glucopyranose unit linked to $\mathrm{C}-3^{\prime}$ of the ethyl $\beta$-D-glucuronate unit and the $\alpha$-L-rhamnopyranose unit linked to $\mathrm{C}-4^{\prime \prime}$ of $\beta$-D-glucopyranose. On the basic of evidences, compound 1 was defined as 3-O$\alpha$-L-rhamnopyranosyl-( $1 \rightarrow 4)$ - $\beta$-D-glucopyranosyl$(1 \rightarrow 3)-6^{\prime}$-O-ethyl- $\beta$-D-glucuronyl oleanolic acid. Compound 2 was obtained as white amorphous powder. In the ${ }^{13} \mathrm{C}$-NMR spectrum, there were 36 signals including 30 signals of a triterpenoid skeleton and 6 signals of a sugar moiety. Two signals of olefin carbons at $\delta_{C} 121.7(\mathrm{C}-12), \delta_{C} 143.5(\mathrm{C}-13)$ and the carbon resonance of an ester group at $\delta_{C} 175.3(\mathrm{C}-28)$ similar to those of oleanolic acid ${ }^{16}$. In the ${ }^{1} \mathrm{H}-\mathrm{NMR}$ spectrum, there were seven singlet signals of methyl groups in the high field at $\delta_{H} 0.89$ (s, H-23), 0.69 (s, $\mathrm{H}-24), 0.67$ (s, H-25), 0.87 (s, H-26), 1.08 (s, H-27), 0.88 (s, H-29), 0.85 (s, H-30), the signal at $\delta_{H} 5.15$ $(\mathrm{m}, \mathrm{H}-12)$ of oleanene skeleton. These signals helped to predict the aglycone moiety could be oleanolic acid. Moreover, the ${ }^{1} \mathrm{H}-\mathrm{NMR}$ spectrum also showed the presence of a $\beta$-D-glucopyranose with a doublet of the anomeric proton at $\delta_{H} 5.24(1 \mathrm{H}, d, 8.0 \mathrm{~Hz})$, 


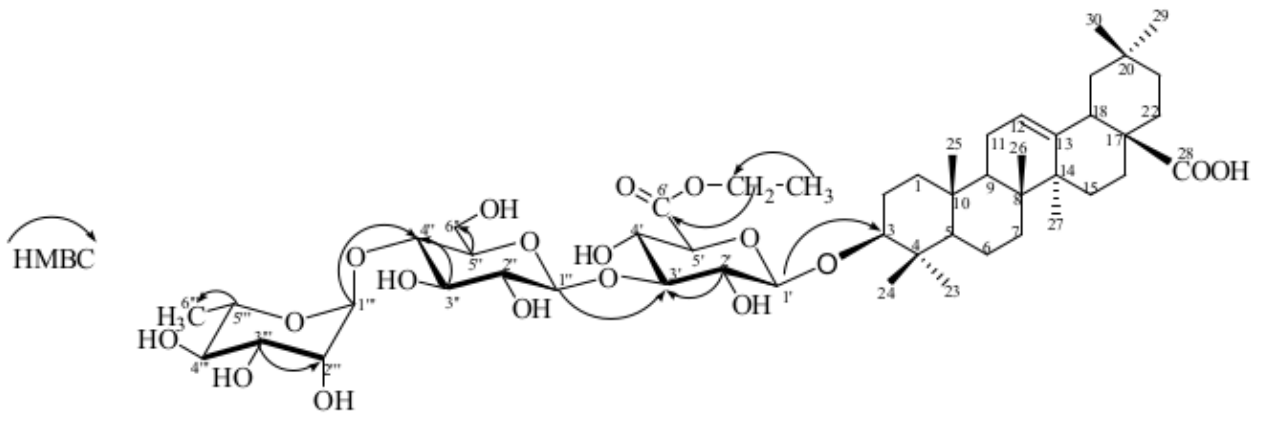

Figure 2: The key HMBC correlations of compound 1.

and signals of sugar protons in the zone 3.10-3.62 ppm. These data indicated that compound 2 could be a triterpenoid glycoside. In the HMBC spectrum, the correlation between $\mathrm{H}-1^{\prime}\left(\delta_{H} 5.24\right)$ of the $\beta$-Dglucopyranose and C-28 $\left(\delta_{C} 175.3\right)$ of the aglycone indicated that the glucose linked to C-28 of the aglycone through an ester linkage. Other HBMC correlations were presented in Figure 3. These NMR spectral data were similar to the one of oleanolic acid 28-O- $\beta$ D-glucopyranoside in the literature ${ }^{17}$. Therefore, the structure of 2 was suggested to be oleanolic acid 28$O$ - $\beta$-D-glucopyranoside.

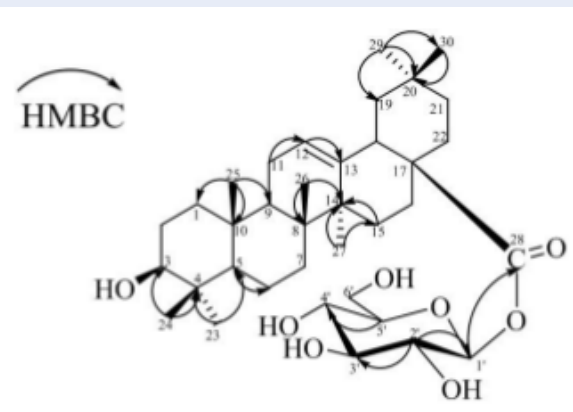

Figure 3: The chemical structure and keys of HMBC correlations of 2.

Compound 3 was collected as a white amorphous powder. In the HRESIMS spectrum, the pseudo molecular ion peak at $m / z 775.4592[\mathrm{M}+\mathrm{Na}]^{+}$, corresponding to $\left[\mathrm{C}_{41} \mathrm{H}_{68} \mathrm{O}_{12}+\mathrm{Na}\right]^{+}, 775.4608$, demonstrating the molecular formula to be $\mathrm{C}_{41} \mathrm{H}_{68} \mathrm{O}_{12}$. The ${ }^{1} \mathrm{H}$ NMR spectrum of the aglycone portion of $\mathbf{3}$ present ed signals for eight tertiary methyl groups $\left(\mathrm{d}_{H}\right.$ $0.74,0.77,0.90,0.91,0.95,0.95,1.24,2.09$ ), four signals for secondary alcoholic functions at $\delta 3.96(\mathrm{~d}$, 7.5, 12-OH), 3.69 (m, H-12) and 4.10 (d, 5.6, 16-OH),
3.58 (m, H-16). The ${ }^{13} \mathrm{C}$ NMR spectrum showed 42 signals including 30 signals of a triterpenoid skeleton and 12 signals of oligosaccharide portions correlating to the corresponding proton chemical shifts from the HSQC experiment. The characteristic signals for the triterpenoid portion were also found in ${ }^{13} \mathrm{C}$ NMR, including an acetyl group at $\delta_{C} 213.8$ (C$22)$ and three oxygenated carbons at $\delta_{C} 87.9$ (C-3), 67.3 (C-12), 64.1 (C-16), eight methyl groups at $\delta_{C}$ 27.4 (s, H-23), 16.1 (s, H-24), 15.6 (s, H-25), 16.6 (s, H-26), 18.5 (s, H-27), 17.2 (s, H-28), 20.1 (s, H29), 25.8 (s, H-30). The downfield chemical shift attributed to $\mathrm{H}-12\left(\delta_{H} 3.69, m\right)$ and the signal of a hydroxyl group at $\delta_{H} 3.96(1 \mathrm{H}, d, 7.5 \mathrm{~Hz}, 12-\mathrm{OH})$ displayed $\mathrm{HMBC}$ correlations with signals at $\delta_{C} 67.3$ $(\mathrm{C}-12)$ and $\delta_{C} 54.5(\mathrm{C}-13)$ suggesting the presence of hydroxyl group at C-12 $\left(\delta_{C} 67.3\right)$. Moreover, the NOESY spectrum showed the correlation between the signals at $\delta_{H-12} 3.69$ and $\delta_{H-29} 1.24$, proving that the hydroxyl group at C-12 was $\beta$-orientation. The location of the hydroxylmethine at $\mathrm{C}-16$ was determined by the analysis of COSY and HMBC data. The signal at $\delta_{H} 4.10(1 \mathrm{H}, d, 5.6 \mathrm{~Hz}, 16-\mathrm{OH})$ displayed HMBC correlations with signals at $\delta_{C} 44.4(\mathrm{C}-15)$ and $\delta_{C}$ 62.9 (C-17), confirming the presence of the hydroxyl group at C-16 $\left(\delta_{C} 64.1\right)$. The coupling constants exhibited two 1,2-diaxial ${ }^{1} \mathrm{H}_{-}{ }^{1} \mathrm{H}$ coupling values to $\mathrm{H}_{a^{-}}$ $17(\mathrm{~d}, 11.4 \mathrm{~Hz}, 1.61)$ with $\mathrm{J}_{16 a-17 a}=15.5 \mathrm{~Hz}$ and $\mathrm{H}_{a^{-}}$ $15(\mathrm{~m}, 1.40,1.15)$ with $\mathrm{J}_{16 a-15 a}=10.1 \mathrm{~Hz}$, which indicated that $\mathrm{H}-17$ should be at axial position. The $\beta$ orientation of the hydroxyl group was confirmed on the basis of NOESY correlations with cross-peaks between $\mathrm{H}_{a x}-16$ and $\mathrm{H}_{e q}-15, \mathrm{H}_{3}-27$ and $\mathrm{H}_{a x}-16$, revealing their spatial proximity. The $\mathrm{HMBC}$ correlations of $\mathrm{H}-17$ to C-16, C-18, and C-21, in accordance with ${ }^{1} \mathrm{H}$ ${ }^{1} \mathrm{H}$ COSY correlations of $\mathrm{H}-16 / \mathrm{H}-17$ indicated the hydroxyl group at C-16 (Figure 4). These data indicated 
that proton $\mathrm{H}-16$ should be at axial position due to an isotropic magnetic effect on cyclohexane. From these data, the aglycone was elucidated as spergulagenin $\mathrm{A}^{18}$. In the ${ }^{1} \mathrm{H}$ NMR spectrum, the sugar portion of 3 exhibited two anomeric proton signals at $\delta_{H} 4.15$ (d, $\left.7.5 \mathrm{~Hz}, \mathrm{H}-1^{\prime}\right)$ and $\delta_{H} 5.01$ (s, H-1 ${ }^{\prime \prime}$ ), and one methyl doublet at $1.08\left(1 \mathrm{H}, d, 6.0 \mathrm{~Hz}, \mathrm{H}-6^{\prime \prime}\right)$ suggesting the occurrence of one deoxyhexose unit. The structures of the oligosaccharide units were deduced using COSY, HSQC, HMBC experiments, which indicated the presence of a $\beta$-D-xylopyranose unit and an $\alpha$ L-rhamnopyranose unit. In the ${ }^{13} \mathrm{C} N \mathrm{NM}$, the sugar moieties were also demonstrated due to an anomeric carbon $\left(\delta_{C-1^{\prime}}=105.8\right)$ and oxygenated methylene ( $\left.\delta_{C-5^{\prime}}=65.4 \mathrm{ppm}\right)$ belonging to the $\beta$-D-xylopyranose unit and an anomeric carbon at $\left(\delta_{C-1^{\prime \prime}}=100.5\right)$ and a methyl group $\left(\delta_{C-6^{\prime \prime}}=18.5 \mathrm{ppm}\right)$ possessed by the $\alpha$-L-rhamnose. The type of sugar was confirmed upon the anomeric proton analysis of the sugar portions prepared by acid hydrolysis. Compound $\mathbf{3}$ was hydrolyzed in a solution of $0.2 \mathrm{M} \mathrm{HCl}$ to afford some monosaccharide units. The anomeric signals of two monosaccharides at $\left[\delta_{H} 5.23(\mathrm{~d}, 3.5 \mathrm{~Hz}, 32 \%)\right.$ and $\left.\delta_{H} 4.61(\mathrm{~d}, 8.0 \mathrm{~Hz}, 68 \%)\right]$ and $\left[\delta_{H} 5.15(b r s, 55 \%)\right.$, $\delta_{H} 4.91(\mathrm{~s}, 45 \%), \delta_{H} 1.32(\mathrm{~d}, 5.5 \mathrm{~Hz}, 47 \%)$ and $\delta_{H}$ $1.30(\mathrm{~d}, 6.0 \mathrm{~Hz}, 53 \%)$ ], were consistent with those of the xylose unit and the rhamnose unit, respectively ${ }^{14}$. The above data indicated that 3 could be a hopane diglycoside. In the HMBC spectrum (Figure 4), the correlation between the $\beta$-D-xylopyranose unit with the anomeric proton $\delta_{H-1^{\prime}} 4.15(1 \mathrm{H}, d, 7.5 \mathrm{~Hz})$ and signal at $\delta_{C} 87.9(\mathrm{C}-3)$ confirmed the attachment of the $\beta$-D-xylopyranose moiety to carbon $\mathrm{C}-3$ of the aglycone. Thus, the sugar moiety attached directly to hopane is $\beta$-D-xylopyranose. The HMBC spectra also showed the correlation between the anomeric proton $\mathrm{H}-1^{\prime \prime}$ of $\alpha$-L-rhamnose $\left(\delta_{H-1^{\prime \prime}} 5.01\right)$ and C$3^{\prime}$ of $\beta$-D-xylopyranose $\left(\delta_{C} 80.8\right)$, which confirmed the attachment of the $\alpha$-L-rhamnose to C-3' of the $\beta$ $\mathrm{D}$-xylopyranose. Therefore, compound 3 was determined as 3-O- $\alpha$-L-rhamnopyranosyl-( $1 \rightarrow 3)-\beta$-Dxylopyranosylhopane-12 $\beta, 16 \beta$-diol-22-one or spergulacin ${ }^{19}$.

Three pure compounds isolated from methanol extract of the Olax imbircata root were structurally elucidated as triterpenoid glycosides. To the best of our knowledge, 3-O- $\alpha$-L-rhamnopyranosyl$(1 \rightarrow 4)$ - $\beta$-D-glucopyranosyl-( $1 \rightarrow 3)-6^{\prime}$ - $O$-ethyl- $\beta$ -

D-glucuronyl oleanolic acid (1) is a new compound. Oleanolic acid 28-O- $\beta$-D-glucopyranoside (2), an oleanane-type saponin, has been isolated from the root bark of Aralia armata ${ }^{20}$. Spergulacin (3), a rearranged triterpene with modified hopane skeleton, has been separa ted from the aerial parts of Mollugo spergula ${ }^{19}$. However, this is the first time the compounds 2 and 3 were isolated from the genus Olax.

The in vitro biological assay of compound 2 showed it s strong potential $\alpha$-glucosidase inhibitory activity with the $\mathrm{IC}_{50}$ value of $56.15 \pm 1.31 \mu \mathrm{M}$ compared to acarbose (with the $\mathrm{IC}_{50}$ value of $290.59 \pm 5.25$ $\mu \mathrm{M})$, which is a popular commercial medicine currently. Screening $\alpha$-glucosidase inhibitory activity of the aerial parts of Glinus oppositifolius led to isolation of spergulacin (3) ${ }^{21}$. This research reported that spergulacin $(3)\left(\mathrm{IC}_{50}=628 \pm 80 \mu \mathrm{M}\right)$ was less active than acarbose $^{21}$.

\section{CONCLUSIONS}

From the root's extract of Olax imbricata collected in $\mathrm{Phu}$ Yen province, three triterpenoid glycosides, including 3 - $O$ - $\alpha$-L-rhamnopyranosyl- $(1 \rightarrow 4)-\beta$-Dglucopyranosyl-( $1 \rightarrow 3)-6^{\prime}$-O-ethyl- $\beta$-D-glucuronyl oleanolic acid (1) together with two known ones, oleanolic acid 28-O- $\beta$-D-glucopyranoside (2) and spergulacin (3). The compound $\mathbf{1}$ is a new one, the compounds 2,3 were isolated for the first time from the genus Olax. The compound 2 showed its strong potential $\alpha$-glucosidase inhibitory activity with the $\mathrm{IC}_{50}$ value of $56.15 \pm 1.31 \mu \mathrm{M}$. This result contributed to prove the use of Olax imbricata as diabeties drug in the folklore.

\section{ABBREVIATIONS}

O: Olax

1D and 2D NMR: one-dimensional and twodimensional nuclear magnetic resonance

${ }^{1}$ H NMR: Proton nuclear magnetic resonance

${ }^{13}$ C NMR: Carbon-13 nuclear magnetic resonance

TLC: Thin layer chromatography

DMSO: Dimethyl sulfoxide $\left(\mathrm{CD}_{3} \mathrm{SOCD}_{3}\right)$

HRESIMS: High-resolution electrospray ionization mass spectrometry

HSQC: Heteronuclear single quantum coherence

HMBC: Heteronuclear multiple bond correlation

COSY: Correlated spectroscopy

$s$ : singlet

brs: broad singlet

$d$ : doublet

$\boldsymbol{d d}$ : doublet of doublets

$\boldsymbol{t}$ : triplet

$\boldsymbol{m}$ : multiplet

\section{CONFLICTS OF INTEREST}

The authors declare no competing financial interest. 


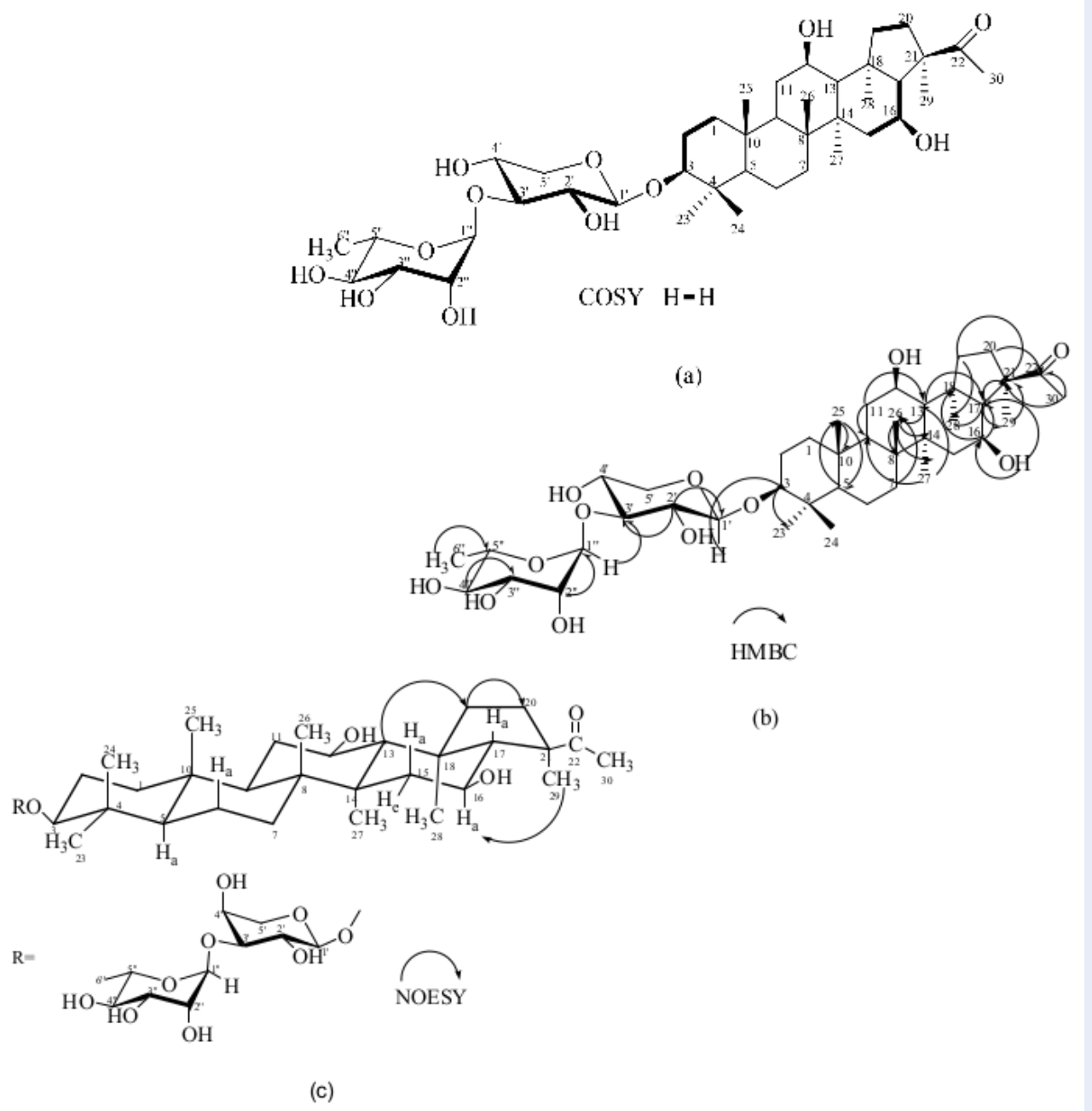

Figure 4: The key COSY (a), HMBC (b), NOESY (c) correlations of compound 3.

\section{AUTHOR CONTRIBUTION}

Huynh Thi Minh Suong and Nguyen Thi My Huong have contributed in conducting experiments, acquiring the data, and writing the draft manuscript. Duong Thuc Huy has contributed to interpreting data. Vo Thi Nga has contributed to analyzing the data, improving and submitting the manuscript. Nguyen Kim Phi Phung has contributed to explaining the data significantly and revising the manuscript.

\section{ACKNOWLEDGMENTS}

This research was supported by a grant from the Ministry of Education and Training (No. B2017.SPK.04). Our thanks are presented for Mr. Hoang Xuan Lam, Middle Vietnam Research and Manufacturing Organic Medicinal Herb Centre for the root sample as the gift for the research.

\section{REFERENCES}

1. Nwaigwe CU, Madubunyi II, Udem SC, Nwaigwe CO. Methanolic root extract of Olax viridis protects the liver against acetaminophen-induced liver damage. Research Journal of Medicinal Plants. 2012;6:395-405.

2. Adeoluwa OA, Aderibigbe AO, Agu GO. Pharmacological evaluation of central nervous system effects of ethanol leaf extract of Olax subscorpioidea in experimental animals. Drug Research. 2016;156:353-357.

3. Adeoluwa OA, Aderibigbe AO, Olonode ET. Antinociceptive property of Olax subscorpioidea Oliv (Olacaceae) extract in mice. Journal of Ethnopharmacology. 2014;66:203-210.

4. Sule MI, Hassan HS, Pateh UU, Ambi AA. Triterpenoids from the leaves of Olax mannii Oliv. Nigerian Journal of Basic and Applied Sciences. 2011;19:193-196.

5. Forgacs P, Provost J, Olaxoside. A saponin from Olax andronensis, Olax glabriflora and Olax psittacorum. Phytochemistry. 1981;20:1689-1691.

6. Peter PT, John SP, Rasins E, Ghisalberti EL. S-ethenyl cysteine, an amino acid from Olax phyllanthi. Phytochemistry. 1993;34:657-659.

7. Sule MI, Haruna AK, Pateh UU, Ahmadu AA, Ambi AA, Sallau MS. Phytochemical investigations of leaf, fruit and root bark of 
Olax mannii Oliv Olacaceae. . ChemClass Journal. 2005;2:2224.

8. Okoye F, Sawadogo WR, Sendker J, Aly AH, Quandt B, Wray V, et al. Flavonoid glycosides from Olax mannii: Structure elucidation and effect on the nuclear factor kappa B pathway. Journal of Ethnopharmacology. 2015;176:27-34.

9. Okoye FBC, Ngwoke KG, Debbab A, Osadebeb PO, Proksch P. Olamannosides $D$ and E: Further kaempferol triglycosides from Olax mannii leaves. Phytochemistry Letter. 2016;16:152155.

10. Kannika P, Panee S, Preeyawis NU, Surapol N, Sunee C, Chan VO. Phytochemical, antioxidant and antibacterial activities of medicinal plants used in Northern Thailand as postpartum herbal bath recipes by the Mien (Yao) community. Phytopharmacology. 2012;2:92-105.

11. Huynh TMS, Vo TN, Nguyen KPP. Phenolic compounds from Olax imbricata. Vietnam Journal of Chemistry. 2015;53:81-84.

12. Huynh TMS, Nguyen TMH, Nguyen KPP, Vo TN. Some phenolic glycosidic compounds from Olax imbricata. Vietnam Journal of Chemistry. 2018;56(3E12):336-342.

13. Nguyen TMH, Vo TN, Huynh TMS, Aree T, Tip-Pyang $S$, Phan DCT, et al. A sesquiterpenoid tropolone and 1,2,3,4tetrahydronaphthalene derivatives from Olax imbricata roots. Fitoterapia. 2019;132:1-6.
14. Giner JL, Feng J, Kiemle DJ. NMR tube degradation method for sugar analysis of glycosides. Journal of Natural Products. 2016;79:2413-2417.

15. Hakamata W, Kurihara M, Okuda H, Nishio T, Oku T. Design and screening strategies for alpha-glucosidase inhibitors based on enzymological information. Current Topics in Medicinal Chemistry. 2009;9(1):3-12.

16. Mahato SB, Kundu AP. Review Article Number 98: 13 C NMR spectra of pentacyclic triterpenoids - A compilation and some salient features. Phytochemistry. 1994;37(6):1517-1575.

17. Yang H, Kim JY, Kim SO, Yoo YH, H SS. Complete $1 \mathrm{H}-\mathrm{NMR}$ and 13C-NMR spectral analysis of the pairs of 20(S) and 20(R) ginsenosides. Journal of Ginseng Research. 2014;38(3):194-202.

18. Barua AK, Ray S, Dutta PK, Venkateswaran RV. A triterpene glycoside from Mollugo spergula. Phytochemistry. 1986;25:1762-1764.

19. Sahua NP, Koikeb K, Banerjeea S, Acharia B, Nikaidob T. Triterpenoid saponins from Mollugo spergula. Phytochemistry. 2001;58:1177-1182.

20. Hu M, Ogawa K, Sashida Y, Xiao PG. Triterpenoid glucuronide saponins from root bark of Aralia armata. Phytochemistry. 1995;39(1):179-184.

21. Kumar D, Shah V, Ghosh R, Pal BC. A new triterpenoid saponin from Glinus oppositifolius with alpha-glucosidase inhibitory activity. Natural Product Research. 2013;27(7):624-629. 